of geography in education; Murchison Grant, Mr. G. B. Stigant, hydrographic department of the Admiralty, for studies and mapping of the Japanese coasts ; Back Grant, Mr. G. de Q. Robin, senior British scientist on the Norwegian-British-Swedish Antarctic Expedition of 1949-52, for geophysical explorations in Queen Maud Land; Cuthbert Peek Grant, Mr. Duncan Carse, leader of the South Georgia (Antarctic) Expedition of 1952, for exploratory surveys and mapping; Gill Memorial, Mr. B. H. Farmer, Fellow of St. John's College, Cambridge, for studies of the use of land in Ceylon.

\section{Secondary Technical Schools and Industry}

IN his presidential address on March 21 to the Association of Heads of Secondary Schools, Mr. H. B. Brown, headmaster of the Bordesley Green Technical School, Birmingham, referred to the development and present position of secondary technical schools, and pointed out that these schools demand of their pupils a very exacting standard of mental activity with an application tending to combine a comprehensive theory with sound practice. He suggested that industry could feel that the time a pupil spent in such a school after the normal school-leaving age is a real contribution to his or her training and might provide the background for later employment in administration, supervision or design. He recommended that training of a young person for a responsible post in industry or commerce should be regarded as divided between full-time school attendance, instruction within industry and special training, either in industry or in further-education establishments, the whole directed towards developing suitability for a position requiring special skills, aptitudes and responsibility. Mr. Brown looked for more co-operation between industry and the technical schools and expressed concern at the inadequacy of the present supply of teachers of science, applied science and crafis, a shortage which threatens the whole of the science and craft teaching in schools, and which may have repercussions on industry itself. He insisted on the need for technical schools to keep their methods of teaching and curricula, their relations with industry and the needs of the cultural world constantly under review and to anticipate and meet changing demands. It is a principal function of the Association, he maintained, to assist in co-ordinating the professional outlook of its members.

\section{Investigation at Cambridge of the Feldspar Minerals}

THE Nuffield Foundation has offered a grant of $\mathfrak{\$ 4 , 1 5 0}$ in aid of a research project on phase equilibrium relations and atomic structure of the feldspar group of minerals to be undertaken jointly by the Department of Mineralogy and Petrology and the Crystallographic Section of the Cavendish Laboratory at Cambridge. The application of recently developed techniques for feldspar synthesis under controlled conditions and for the rapid X-ray identification of crystalline phases, principally at the Geophysical Laboratory of the Carnegie Institution of Washington, has opened up a fruitful field of research of the first importance, not only for the understanding of the intimate relations within this great mineral group but also for the elucidation of the genetic history of feldspathic rocks, both igneous and metamorphic. The grant provided by the Nuffield Foundation will be utilized at Cambridge for the provision of equipment devised for the application of the new techniques in the investigation of the hydrothermal synthesis, polymorphism and unmixing relations of feldspar phases, and for fundamental crystal analysis studies, especially of synthetic feldspars of known thermal history.

\section{Enzymic Systems in Root Apices}

AN account of a method for determining the development of the enzyme complement in growing root cells has been given by $\mathrm{E}$. Robinson and R. Brown (J. Exp. Bot., 3, 9, 356; 1952). On corresponding successive segments from the root apex backwards, the water and protein contents and the activities of dipeptidase, glycine oxidese and invertase have been measured, together with the number of cells in each segment. From these data it has been possible to indicate how the quantities involved change during cell growth. Four phases ean be distinguished in the early cellular development. During a cell's development in the meristematic region its volume increases slightly, the protein content probably decreases, and the activities of three of the enzymes studied decrease. During the second phase there is a large increase in cell volume and protein content, and all enzymic activities increase considerably. In the third phase, the cell increases in volume by increase in breadth, but its protein content and enzyme activities decrease. The fourth phase is marked by cessation of growth and a continued decrease in protein content and enzyme activity. In discussing their results, the authors point out that the enzyme activity varies directly with the protein level during all four phases, and that the enzymatic constituents account for, if not the whole, at least a considerable part of the total protein content. The possibility is considered that during cell growth there are changes in the composition and structure of the protein complex and that such changes are causally related to variation in the relative activities of the different enzymes. Whether cell growth is determined by changes in the protein contents and other related topics are discussed.

\section{Stop-watches and Chronographs}

INSTRUMENTS capable of measuring and recording intervals of time to a fine degree of accuracy are required in many walks of life and particularly by the engineer and scientific worker in modern industry. Stop-watches and chronographs are mainly used; but few people understand the underlying mechanism, the degree of accuracy that can be expected and how to select the most suitable type for the work to be measured. The completely revised and reprinted catalogue of high-precision Swiss stop-watches and chronographs, recently issued by the firm of Camerer Cuss and Co. (54-6 Now Oxford Street, London, W.C.1), which has specialized in horology since 1788 , is, in spite of its small size, particularly valuable because it contains, in a preface, just those details which will assist the purchaser in the selection of the correct instrument. 'The function and action of the escapement is explained, how inaccuracies are reduced by proper choice of materials and arrangement is discussed, and the necessity is stressed for a periodical overhaul if a watch is to maintain a steady state. Where it is necessary to have a certificate of accuracy, the Metrology Division of the National Physical Laboratory, 'I'eddington, will undertake an independent test. Watches required for the testing of electric meters are tested under the Electricity Supply (Meters) Act, 1936, to a specification issued by the Ministry of Fuel and Power. The instruments 